\title{
New sequence types of Acinetobacter baumannii in two emergency hospitals in the Central-West region of Brazil
}

\author{
Francisco Kennedy Scofoni Faleiros de Azevedo ${ }^{[1]}$, Valéria Dutra ${ }^{[2]}$, Luciano Nakazato ${ }^{[2]}$, \\ Marco Andrey Pepato ${ }^{[1]}$, Alessandra Tammy Hayakawa Ito de Sousa ${ }^{[2],}$ \\ Cassius Clay Scofoni Faleiros de Azevedo ${ }^{[1]}$ and Francisco José Dutra Souto ${ }^{[1]}$
}

\author{
[1]. Departamento de Clínica Médica, Universidade Federal de Mato Grosso, Cuiabá, MT, Brasil. \\ [2]. Hospital Veterinário e Laboratório de Microbiologia Veterinária e Biologia Molecular, Universidade Federal de Mato Grosso, Cuiabá, MT, Brasil.
}

\section{Dear Editor:}

Acinetobacter baumannii, a common causal agent of ventilator-associated pneumonia, is related with high hospital costs and mortality ${ }^{1}$. The 2016 surveillance report of the European Centre for Disease Prevention and Control reported that $49 \%$ of $A$. baumannii isolates were carbapenem resistant ${ }^{2}$. In Brazil, the percentage of this species with resistance to carbapenems is approximately $71 \%$, with similar data for Chile and Argentina ${ }^{3}$. The genes $b l a_{\text {OXA-23 }}, b l a_{\text {OXA-24 }}$ (and its variants $b l a_{\mathrm{OXA}-40}$ and $\left.b l a_{\text {OXA-72 }}\right), b l a_{\text {OXA-58, }}, b l a_{\text {OXA-143, }}$, and $b l a_{\text {OXA-235 }}$ of the Ambler class D $\beta$-lactamases are responsible for carbapenem resistance in $A$. baumannii ${ }^{4}$. Multilocus sequence typing (MLST) is used to determine the sequence type (ST) of isolates, with $A$. baumannii ST15, ST25, ST79, and ST1 being the most common in South America ${ }^{5}$. These clones are clustered in MLST clonal complexes (CC) CC15, CC25, CC79, and CC1, respectively ${ }^{5}$. In Brazil, A. baumannii $\mathrm{ST} 15, \mathrm{ST} 79$, and $\mathrm{ST} 1$ are also frequently found ${ }^{6}$.

A total of nine Acinetobacter spp. isolates were extracted from rectal swab and wound secretion samples from nine patients hospitalized in intensive care units at two public emergency hospitals in Cuiaba and Varzea Grande, Mato Grosso State, Central Brazil: the Municipal Hospital and Emergency Room of Cuiaba, and the Municipal Hospital and

Corresponding author: Dr. Francisco Kennedy Scofoni Faleiros de Azevedo. e-mail: fksfazevedo@gmail.com

Orcid: 0000-0001-7985-6781

Received 19 February 2019

Accepted 8 May 2019
Emergency Room of Varzea Grande. Rectal swabs and wound secretion samples were collected from the patients for routine surveillance by the hospital infection control committees between June 2012 and August 2012. Microorganism identification was performed, and drug resistance profiles based on the minimum inhibitory concentration were obtained using the Bact/Alert 3D and Vitek2 systems (BioMérieux, Marcy l'Etoile, France) in the Microbiology Laboratory of the Júlio Muller University Hospital, Cuiaba, Mato Grosso, Brazil. Isolates identified as Acinetobacter spp. were tested for their sensitivity to antimicrobials according to the 2017 Clinical and Laboratory Standards Institute Guidelines ${ }^{7}$. The genomic DNA extraction, polymerase chain reaction (PCR) for the detection of A. baumannii genes, and application of the MLST technique for genotypic analysis of the isolates were performed in the Laboratory of Veterinary Microbiology and Molecular Biology, College of Veterinary Medicine, Federal University of Mato Grosso, Mato Grosso, Brazil ${ }^{8-10}$.

The research protocol (\#850.791) was approved by the Ethics Research Committee of the Julio Muller Hospital, and was registered in the National System of the Ethical Evaluation of Human Research Projects (CAAE 28637414.0.0000.5541). The A. baumannii isolates were confirmed by the PCR-based amplification of the bla $a_{\mathrm{OXA}-51}$ gene. The patient demographics and the isolates' in vitro resistance to antimicrobials are detailed in Table 1.

The A. baumannii isolates analyzed in this study showed resistance to imipenem and other drugs, as well as sensitivity to polymyxin $\mathrm{B}$, similar to the trends reported in other regions of Brazil and in other countries ${ }^{2,3,9}$. The bla $_{\text {OXA-23 }}$ gene was most frequently found. These data are similar to those of other international and Brazilian studies ${ }^{5,6,9}$. Other genes associated 
TABLE 1: Clinical characteristics of the nine hospitalized patients, and in vitro susceptibility to imipenem, resistance genes, sequence types, and clonal complexes of Acinetobacter baumannii isolates, from two emergency hospitals in the Center-West region of Brazil.

\begin{tabular}{|c|c|c|c|c|c|c|c|c|c|c|c|c|}
\hline Patient & $\begin{array}{c}\begin{array}{c}\text { Age } \\
\text { (year), } \\
\text { Sex }^{\mathrm{a}}\end{array}\end{array}$ & Sample $^{\mathrm{b}}$ & Imipenem $^{c}$ & $\begin{array}{l}\text { Time to } \\
\text { isolation } \\
\text { (day) }\end{array}$ & Hospital $^{d}$ & $\begin{array}{c}\text { Prior } \\
\text { treatment }\end{array}$ & Outcome & $\begin{array}{l}\text { bla } \text { oxa-23 }^{\text {I }} \\
\text { ISAAba1 }\end{array}$ & $b / a_{\mathrm{OXA}-24}$ & $b / a_{\text {OXA-143 }}$ & $\begin{array}{l}\text { Sequence } \\
\text { type (ST) }\end{array}$ & $\begin{array}{l}\text { Clonal } \\
\text { complex } \\
\text { (CC) }\end{array}$ \\
\hline 2 & $35, \mathrm{M}$ & RS & $\mathrm{R}$ & 19 & A & $\begin{array}{l}\text { PIPE/TAZ, } \\
\text { IMP, VAN }\end{array}$ & Recovery & + & - & - & 108 & 108 \\
\hline 4 & $41, \mathrm{~F}$ & RS & $\mathrm{R}$ & 20 & A & $\begin{array}{l}\text { PIPE/TAZ, } \\
\text { VAN }\end{array}$ & Recovery & + & + & - & 108 & 108 \\
\hline 5 & $45, \mathrm{M}$ & RS & $\mathrm{R}$ & 50 & B & $\begin{array}{l}\text { PIPE/TAZ, } \\
\text { VAN }\end{array}$ & Recovery & + & + & - & 162 & 162 \\
\hline 6 & $23, \mathrm{M}$ & Ws & S & 33 & B & CEFE & Recovery & + & - & - & 985 & 79 \\
\hline 9 & $42, \mathrm{~F}$ & RS & $\mathrm{R}$ & 27 & B & PIPE/TAZ & Recovery & + & + & + & $N P^{h}$ & $\mathrm{NP}$ \\
\hline
\end{tabular}

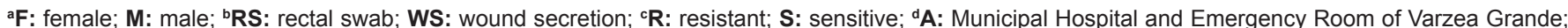
B: Municipal Hospital and Emergency Room of Cuiaba; eIMP: imipenem; PIPE/TAZ: piperacillin/tazobactam; CEFE: cefepime; CEFA: cephalothin; CEFI: ceftriaxone; VAN: vancomycin; ${ }^{\text {f }}$ Clonal complex according to the eBurst classification; ${ }^{9}$ ST984: identified for the first time in this study and classified as a singleton by eBurst; ${ }^{\mathrm{N} P}$ : not performed.

with carbapenem resistance were $b l a_{\text {OXA-24 }}$ and $b l a_{\text {OXA-143. The }}$ bla $a_{\text {OXA-24 }}$ gene is more prevalent in some countries, such as Ecuador and Mexico, and is uncommon in Brazil ${ }^{5,6,11}$. However, it was the second most prevalent carbapenem resistance gene found in another study conducted in the Center-West region of Brazil ${ }^{9}$. The bla ${ }_{\mathrm{OXA}-143}$ gene, which has been detected in southeastern, southern, and central Brazil, was again found in the Center-West region of the country ${ }^{9,10}$. The $b l a_{\mathrm{OXA}-58}$, bla $_{\mathrm{KPC}}$, and bla $_{\mathrm{NDM}}$ genes were not found. Phylogenetic classification by MLST revealed the presence of ST108, ST162, and ST1, which are commonly found in South American countries, including Brazil ${ }^{5,6,9}$. Interestingly, one of the isolates corresponded to ST409, a sequence type first described in Egypt, and was never described in Brazil until now ${ }^{12}$. Three new STs (ST984, ST985, and ST987) were found.

The isolates reported here were recovered form surveillance cultures, and only one patient evolved to death. However, the finding of isolates of different multidrug-resistant $A$. baumannii STs deserves the attention and concern of local health authorities owing to the extended antimicrobial resistance profile of this microorganism. More research is warranted to assess the impact of this multidrug-resistant bacterium on the generation of threatening infections in the study region.

\section{Conflict of Interest}

The authors declare that there is no conflict of interest.

\section{Financial Support}

This research had financial support from the Brazilian National Council for Scientific and Technological Development $(\mathrm{CNPq})$, a federal agency for research support, through a research incentive grant for Francisco José Dutra Souto.
Accession numbers of new sequences reported in the article (https://pubmlst.org/abaumannii/): ST984, ST985, and ST987.

\section{REFERENCES}

1. Busani S, Serafini G, Mantovani E, Venturelli C, Giannella M, Viale $\mathrm{P}$, et al. Mortality in patients with septic shock by multidrug resistant bacteria. J Intensive Care Med. 2017; 34(1):48-54.

2. European Centre for Disease Prevention and Control. Surveillance of Antimicrobial Resistance in Europe 2016." Annual Report of the European Antimicrobial Resistance Surveillance Network (EARSNet). Stockholm: ECDC; 2017.

3. Gales AC, Castanheira M, Jones RN, Sader HS. Antimicrobial Resistance Among Gram-Negative Bacilli Isolated from Latin America: results from SENTRY Antimicrobial Surveillance Program (Latin America, 2008-2010).” Diagn Microbiol Infect Dis. 2012;73(4):354-60.

4. Poirel L, Nordmann P. Carbapenem Resistance in Acinetobacter baumannii: Mechanisms and Epidemiology." Clin Microbiol Infect. 2006;12(9):826-836.

5. Rodríguez CH, Balderrama Yarhui N, Nastro M, Nuñez Quezada T, Castro Cañarte, Magne Ventura R, et al. Molecular Epidemiology of Carbapenem-Resistant Acinetobacter baumannii in South America.” J Med Microbiol. 2016;65(10):1088-91.

6. Chagas TP, Carvalho KR, de Oliveira Santos IC, Carvalho-Assef AP, Asensi MD. Characterization of Carbapenem-Resistant Acinetobacter baumannii in Brazil (2008-2011): Countrywide Spread of OXA-23-Producing Clones" (CC15 and CC79). Diagn Microbiol Infect Dis. 2014;79(4):468-72.

7. Clinical \& Laboratory Standards Institute. Performance Standards for Antimicrobial Susceptibility Testing: $27^{\text {th }}$ informational supplement M100." Wayne, PA: Clinical and Laboratory Standards Institute. 2017;46-8. 
8. Sambrook J, Fritsch EF, Maniatis T. Molecular Cloning: A Laboratory Manual, 2nd ed., Cold Spring Harbor Laboratory Press, Cold Spring Harbor, NY. 1989.

9. de Azevedo FKSF, Dutra V, Nakazato L, Mello CM, Pepato MA, de Sousa ATHI, et al. Molecular Epidemiology of MultidrugResistant Acinetobacter baumannii Infection in Two hospitals in Central Brazil: The Role of ST730 and ST162 in Clinical Outcomes." J Med Microbiol. 2019;68(1):31-40.

10. Antonio CS, Neves PR, Medeiros M, Mamizuka EM, Elmor de Araújo MR, Lincopan N. High Prevalence of CarbapenemResistant Acinetobacter baumannii Carrying the blaOXA-143
Gene in Brazilian Hospitals." Antimicrob Agents Chemother. 2011;55(3):1322-3.

11. Alcántar-Curiel MD, García-Torres LF, González-Chávez MI, Morfín-Otero R, Gayosso-Vázquez C, Jarillo-Quijada MD, et al. Molecular Mechanisms Associated With Nosocomial CarbapenemResistant Acinetobacter baumannii in Mexico." Arch Med Res. 2014;45(7):553-60.

12. Al-Hassan L, El Mehallawy H, Amyes SG. Diversity in Acinetobacter baumannii isolates from paediatric cancer patients in Egypt. Clin Microbiol Infect. 2013;19(11):1082-8. 